УДК 538.9

DOI: $10.17308 / \mathrm{kcmf} .2019 .21 / 716$

Поступила в редакцию 03.12.2018

Подписана в печать 15.02.2019

\title{
РОСТ И СУБСТРУКТУРА ПЛЕНОК НИОБАТА ЛИТИЯ
}

\author{
(ㄷ 2019 В. А. Дыбов*1, Д. В. Сериков ${ }^{1}$, Г. С. Рыжкова ${ }^{1}$, А. И. Донцов ${ }^{2}$ \\ ${ }^{1}$ Воронежский государственный технический университет \\ Московский пр., 14, 394026 Воронеж, Россия \\ ${ }^{2}$ Воронежский государственный университет \\ Университетская пл., 1, 394018 Воронеж, Россия
}

\begin{abstract}
Аннотация. Проведены исследования начальных стадий роста пленок ниобата лития на $\mathrm{Si}$ в процессе ВЧМР, исследования влияния условий ВЧМР и последующих обработок (ТО, ИФО, БТО) на структуру, субструктуру и ориентацию получаемых покрытий. Установлено, что начальные стадии роста пленок ниобата лития в процессе ВЧМР на подогретой до $550{ }^{\circ} \mathrm{C} \mathrm{Si} \mathrm{подложке}$ характеризуются островковым зарождением кристаллитов и последующей их коалесценцией. Показана возможность управления текстурой пленок ниобата лития в процессе ВЧМР в условиях воздействия плазмы ВЧ-разряда, путем изменения состава рабочего газа. Показан эффект ИФО в кристаллизации аморфных пленок состава ниобата лития, заключающийся в формировании однофазной нанокристаллической пленки ниобата лития, в процессе обработки на воздухе.
\end{abstract}

Ключевые слова: ниобат лития, тонкие пленки, высокочастотное магнетронное распыление, рост, структура, термическая обработка, импульсная фотонная обработка.

\section{ВВЕДЕНИЕ}

В настоящее время применение ниобата лития в качестве материала для функциональных сегнетоэлектрических элементов, для оптоэлектроники (оптические волноводы, кольцевые микрорезонаторы), акустоэлектроники (пьезоэлектрические преобразователи в линиях задержки, фильтрах) и полупроводниковой электроники (ячейки энергонезависимой памяти FRAM), реализовано для монокристаллов ниобата лития, необходимые геометрические параметры которых формируют весьма трудоемкими и малопроизводительными методами. Использование пленок ниобата лития может значительно упростить технологию изготовления таких элементов и позволит внедрить их при производстве обычных CMOS-структур, внеся некоторые дополнения в существующую технологию. Эффективность использования пленок ниобата лития связана, во-первых, с реализацией в них нелинейных физических свойств, аналогичных монокристаллам (высокотекстурированные пленки), во-вторых, с формированием межфазных границ подложка-пленка с долговременной химической и структурной стабильностью. В то время как синтез ориентированных пленок ниобата лития, основанный на гетероэпитаксии, реализован метода-

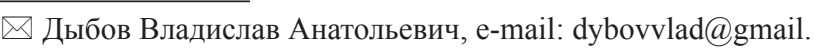
com ми жидкофазной эпитаксии [1], золь-гель методом [2], химическим осаждением из паровой фазы [3], методом лазерной абляции $[4,5]$ на диэлектрических подложках с соответствующими ниобату лития параметрами кристаллической решетки (например, сапфире), а также кремнии, модифицированном барьерными слоями $\mathrm{Si}_{3} \mathrm{~N}_{4}$ [6], $\mathrm{ZnO}$ [7], информация о синтезе указанными методами текстурированных покрытий на основе ниобата лития непосредственно на неориентирующих подложках, в частности, на немодифицированной поверхности кремния, практически отсутствует. Кроме того, не все вышеперечисленные методы применимы для нанесения пленок ниобата лития на полупроводниковые подложки для интегральной электроники в связи с температурой процесса синтеза, превышающей порог начала твердофазных реакций на границе подложка-пленка (жидкофазную эпитаксию и химическое осаждение проводят при температуре выше $\left.900{ }^{\circ} \mathrm{C}\right)$.

Одним из наиболее перспективных методов синтеза пленок ниобата лития является высокочастотное магнетронное распыление (ВЧМР), широко используемое для нанесения пленок сложных оксидов. Известно, что условия процесса ВЧМР (состав и давление рабочего газа, мощность и пространственная неоднородность плазменного разряда, потенциал на подложке) открывают широкие 
возможности управления структурой и, в частности, текстурой пленок сложного состава [8]. В работе [10] была показана возможность синтеза методом ВЧМР пленок ниобата лития с одноосной [0001] текстурой на поверхности кремния, показано, что одним из факторов, влияющих на формирование текстуры, является воздействие компонентов плазмы на растущую пленку. При этом отсутствуют работы по исследованию начальных стадий роста пленок ниобата лития в процессе ВЧМР, на каких-либо подложках. Знание механизма и условий формирования субструктуры приграничного с подложкой тонкого (до нескольких десятков $\mathrm{nm})$ слоя пленки играет важную роль как в понимании механизма формирования объемных слоев покрытий в процессе роста и обработок относительно толстых (до нескольких $\mu \mathrm{m}$ ) покрытий, так и в возможностях изменения физических свойств (оптических, акустических и др.) гетероперехода пленка-подложка.

Для кристаллизации аморфных структур, получаемых при низкотемпературной конденсации, формирования равновесной структуры в кристаллических пленках ниобата лития используется термический отжиг в кислородосодержащей среде. Однако постконденсационный отжиг гетероструктур кремний - ниобат лития и кремний окисленный кремний - ниобат лития, связанный с использованием высоких температур, приводит к значительным напряжениям в пленках и твердофазным реакциям на межфазной границе подложка-пленка. В связи с этим сохраняет актуальность задача разработки приемов обработки гетероструктур с низкой термической нагрузкой. Перспективной является быстрая термическая обработка, эффективность использования которой в кристаллизации аморфных пленок состава $\mathrm{LiNbO}_{3}$ показана в работе [11], а также импульсная фотонная обработка (ИФО), эффективность которой была показана на примере синтеза силицидов, карбидов и оксидов [12, 13].

\section{МЕТОДИКА ЭКСПЕРИМЕНТА И МЕТОДЫ ИССЛЕДОВАНИЯ}

Пленки ниобата лития толщиной до $1 \mu \mathrm{m}$ получали методом высокочастотного магнетронного распыления (ВЧМР) на неподгреваемых и подогреваемых (до $550{ }^{\circ} \mathrm{C}$ ) подложках. В качестве мишени использовали неполированные монокристаллические пластины $\mathrm{LiNbO}_{3}$ ориентации (0001), полученные методом Чохральского (мишени были подготовлены в ФИЦ КНЦ РАН). ВЧМР проводи- ли в среде $\mathrm{Ar}$ и смеси $\mathrm{Ar}+\mathrm{O}_{2}$ (долю содержания $\mathrm{O}_{2}$ в смеси варьировали от 20 до $30 \%$ ) при удельной мощности высокочастотного разряда $15-30 \mathrm{~W} / \mathrm{cm}^{2}$. В качестве подложек использовали пластины монокристаллического Si ориентации (001) и гетероструктуры аморфная пленка $\mathrm{SiO}_{2}-\mathrm{Si}$-аморфная пленка $\mathrm{SiO}_{2}$.

Для исследования начальных стадий роста покрытий методом просвечивающей электронной микроскопии (ПЭМ) на получаемые пленки толщиной до $100 \mathrm{~nm}$ (время процесса ВЧМР 0.5-7 $\mathrm{min}$ ) наносили углеродную реплику, после чего отделяли от подложки (Si) вместе с исследуемым покрытием в смеси $\mathrm{H}_{2} \mathrm{O}+\mathrm{HNO}_{3}+\mathrm{HF}$.

Термическую обработку (ТО) образцов на воздухе производили in situ в камере рентгеновского дифрактометра ARL X'TRA Thermo Techno, печь Anton Paar 1200N. Импульсную фотонную обработку (ИФО) производили на модернизированной установке УОЛП-1М излучением трех газоразрядных ксеноновых ламп ИНП 16/250 в атмосфере воздуха: однократным облучением с длительностью импульса $1.0 \mathrm{~s}$ при плотности энергии $E_{\mathrm{u}}=130 \mathrm{~J} / \mathrm{cm}^{2}$ и шестикратным облучением длительностью $-0.6 \mathrm{~s} \mathrm{c}$ $E_{\text {и }}=80 \mathrm{~J} / \mathrm{cm}^{2}$ и интервалом следования $60 \mathrm{~s}$. Одновременно с ИФО на обратной, не облучаемой стороне образца в силу однородности температурного поля по глубине гетероструктуры (перепад температур не превышает 2.5 К) реализовывался процесс быстрого термического отжига (БТО).

Фазовый состав, субструктуру и морфологические особенности пленок исследовали методами рентгеновской дифрактометрии (Bruker D2 Phaser, ARL X'TRA Thermo Techno), электронографии (ЭГ-100 M), электронной микроскопии (ZEISS Libra 120, ЭМВ-100 БР); анализ элементного состава проводили методом электронной Ожэ-спектроскопии на приборе ЭСО-3 с анализатором DESA-100.

\section{РЕЗУЛЬТАТЫ И ИХ ОБСУЖДЕНИЕ}

\section{Начальные стадии роста}

На рис. 1 представлены ПЭМ-изображения и электронограммы покрытий, полученных в процессе ВЧМР длительностью 0.5-7 min (рис. 1) на нагретой $\left(T_{\Pi}=550{ }^{\circ} \mathrm{C}\right)$ подложке из (001) $\mathrm{Si}$ в условиях воздействия на подложку плазмы ВЧ-разряда (то есть при расположении подложки над 3/э мишени). Из анализа полученных изображений установлено, что при длительности процесса ВЧМР 30 секунд наблюдается формирование кристаллических островков $\mathrm{LiNbO}_{3}$ размером 10-20 $\mathrm{nm}$. При увеличении времени процесса до 4 min наблюдает- 

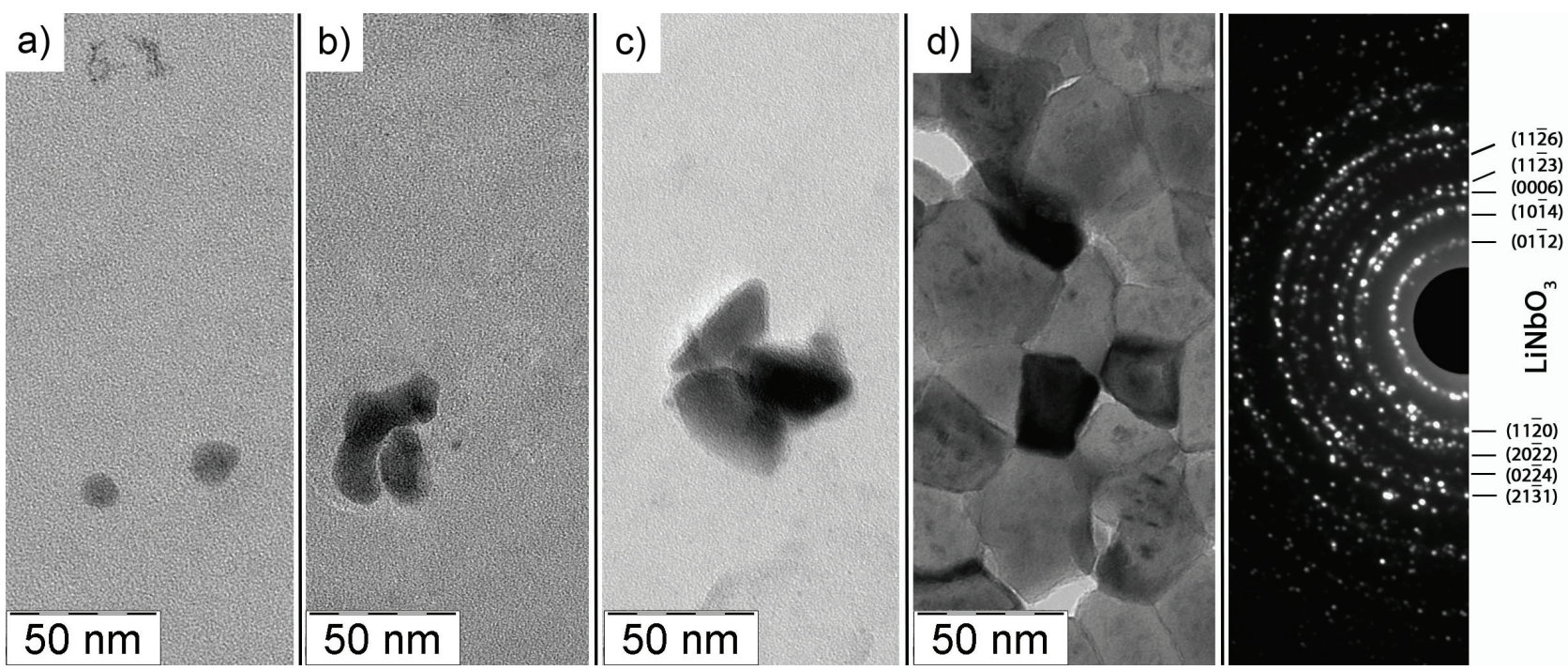

Рис. 1. ПЭМ изображения и электронограмма покрытий, полученных на $\mathrm{Si}$ подложке в процессе ВЧМР мишени $\mathrm{LiNbO}_{3}$, длительность процесса: $a-30$ секунд; $b-2$ мин; $c-4$ мин; $d-7$ мин

[Fig. 1. TEM image and electron diffraction pattern of coatings obtained on a Si substrate in the process of RFMS

$\mathrm{LiNbO}_{3}$ target, process duration: $\left.a-30 \mathrm{sec} ; b-2 \mathrm{~min} ; c-4 \mathrm{~min} ; d-7 \mathrm{~min}\right]$

ся увеличение среднего размера островков до 40-50 $\mathrm{nm}$. ВЧМР в течение 7 min приводит к формированию сплошной кристаллической пленки $\mathrm{LiNbO}_{3} \mathrm{co}$ средним размером зерен 50-60 nm. График зависимости размера кристаллитов от времени процесса представлен на рис. 2. Малая плотность кристаллитов на фрагментах образцов, приготовленных при продолжительности напыления до $4 \mathrm{~min}$, объясняется эрозией части дискретных кристаллитов с углеродной реплики при пробоподготовке в процессе травления (подтравливания) кремниевой подложки в растворе кислот.
На рис. 3 представлены оже-спектры покрытий, полученных на поверхности (001)Si в течение 30 s, 2 и 4-х min. Наличие на всех спектрах пиков, соответствующих $\mathrm{Nb}$ и О (отсутствие пика $\mathrm{Li}$ обусловлено его расположением в области выхода вторичных электронов, вследствие чего регистрация Li данным методом очень затруднительна), свидетельствует о формировании покрытий после 30 секунд распыления. В связи с наличием пика Si на всех спектрах, с учетом глубины выхода оже-электронов можно говорить о несплошности покрытий.

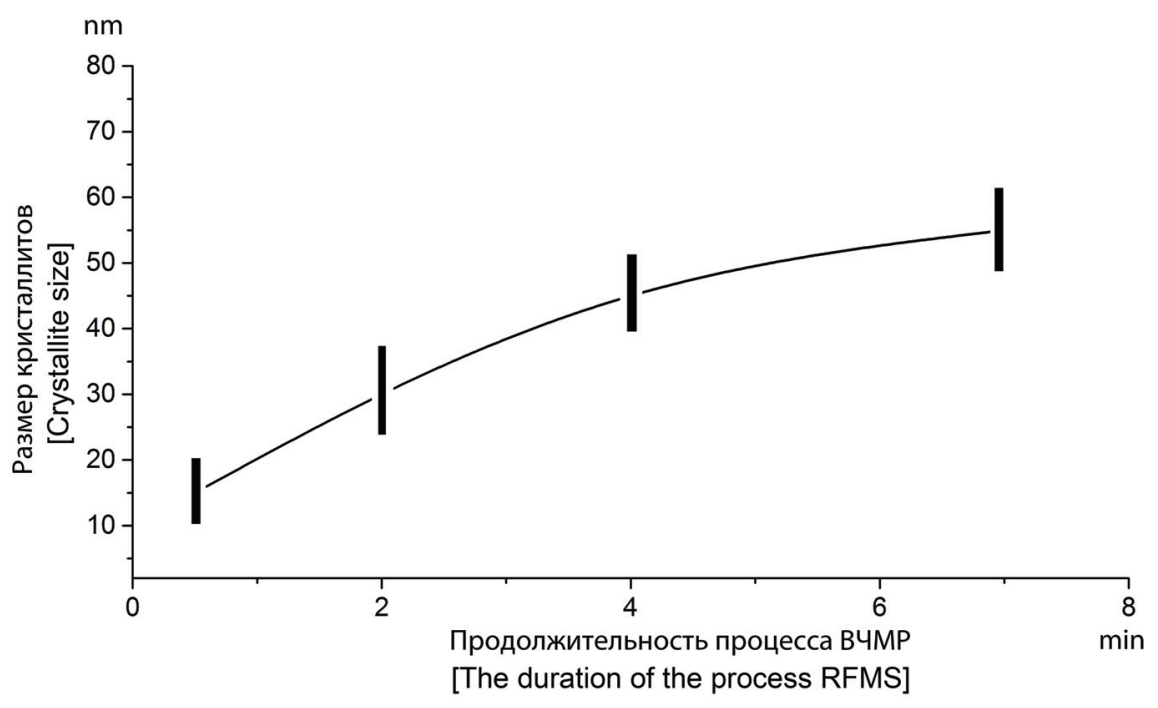

Рис. 2. Зависимость среднего размера кристаллитов от времени процесса ВЧМР

[Fig. 2. The dependence of the average crystallite size on the time of the RFMS process] 


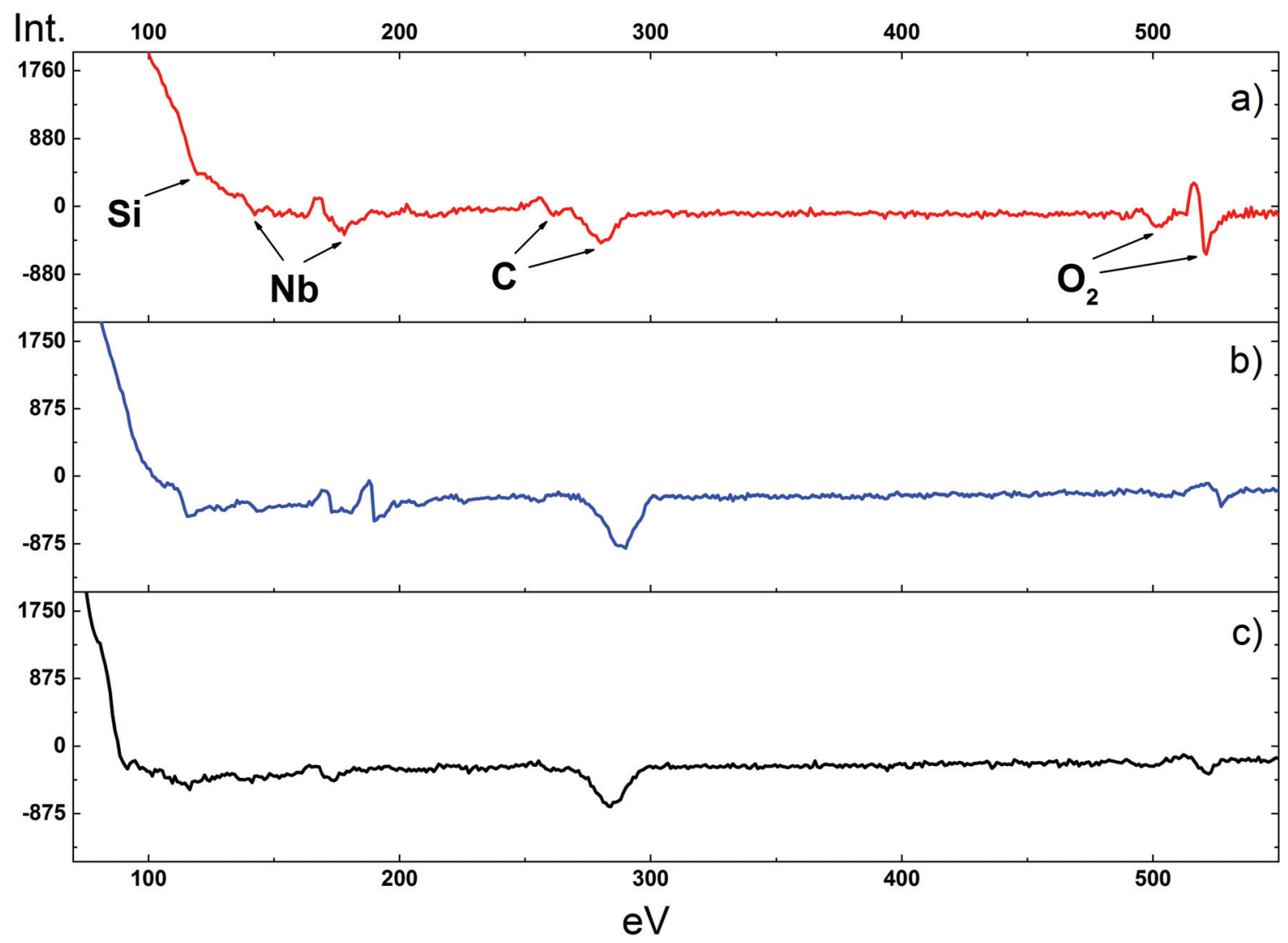

Рис. 3. Оже-спектры покрытий, полученных в процессе ВЧМР на поверхности (001)Si в течение 30 секунд (c), 2-х $(b)$ и 4-х мин $(a)$

[Fig. 3. Auger spectra of coatings obtained in the process of RFMS on the (001) Si surface for 30 seconds (c), 2 minutes $(b)$ and 4 minutes $(a)$ ]

Из анализа полученных результатов можно сделать вывод о том, что данные структурно-морфологические изменения в процессе роста пленок $\mathrm{LiNbO}_{3}$ при высокочастотном магнетронном распылении являются результатом островкового зарождения и последующей коалесценции.

\section{Структура и ориентация кристаллических пленок, полученных в процессе ВЧМР}

На рис. 4 изображены рентгеновские дифрактограммы пленок, полученных на поверхности (001)Si в процессе ВЧМР в условиях воздействия плазмы ВЧ-разряда, то есть при расположении подложки над зоной эрозии мишени на расстоянии $\sim 5 \mathrm{~cm}$, в среде $\mathrm{Ar}$ и $\mathrm{Ar}+\mathrm{O}_{2}$ (в соотношении $80 / 20$ и 70/30 \%) толщиной $~ 300 \mathrm{~nm}$. Наблюдается, что в среде Ar формируются двухфазные пленки с фазой $\mathrm{LiNbO}_{3}(\mathrm{LN})$ с сильно выраженной текстурой $<0001>$ и небольшим содержанием фазы $\mathrm{LiNb}_{3} \mathrm{O}_{8}$ (LTN). При добавлении $\mathrm{O}_{2}$ в состав рабочего газа формируются однофазные пленки (LN) и наблюдается уменьшение текстуры в направлении $<0001>$. При дальнейшем повышении доли $\mathrm{O}_{2}$ в составе рабочего газа наблюдается развитие текстуры в направлении перпендикулярном плоскости (01 $\overline{1} 2)$ (рис. 4). Таким образом, показана возможность управления текстурой пленок ниобата лития, получаемых в процессе ВЧМР в условиях воздействия плазмы ВЧ-разряда, путем изменения состава рабочего газа. Механизм, приводящий к смене текстуры ниобата лития при смене состава рабочего газа, требует дальнейшего изучения.

\section{Структура и ориентация кристаллических пленок, полученных в процессе ТО, БТО и ИФО}

На рис. 5 показаны результаты исследования изменения фазового состава в процессе термической обработки. Установлено, что исходные пленки, полученные на неподогреваемой подложке в среде $\mathrm{Ar}$, имеют аморфную структуру. Начало кристаллизации в процессе ТО наблюдается при температуре $500{ }^{\circ} \mathrm{C}$, при этом происходит формирование двухфазной пленки (LN и LTN). При температуре $650^{\circ} \mathrm{C}$ наблюдается вторичная рекристаллизация, о 


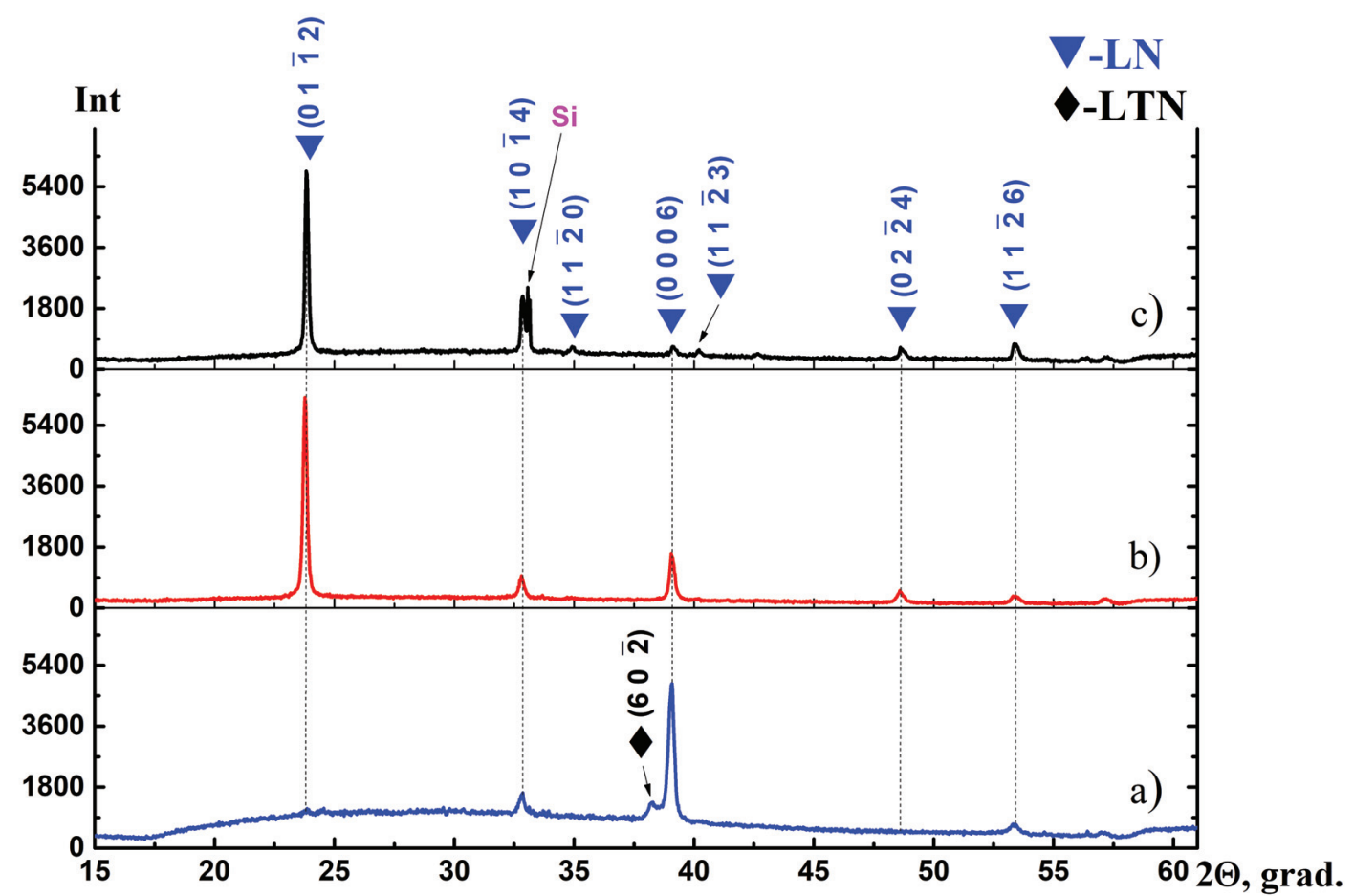

Рис. 4. Рентгеновские дифрактограммы пленок, полученных в процессе ВЧМР монокристаллической мишени $\mathrm{LiNbO}_{3}$ в среде $\operatorname{Ar}(a), \operatorname{Ar}(80 \%)+\mathrm{O}_{2}(20 \%)(b), \operatorname{Ar}(70 \%)+\mathrm{O}_{2}(30 \%)(c)$

[Fig. 4. X-ray patterns of the films obtained in the RFMS process of a single-crystal $\mathrm{LiNbO}_{3}$ target in the atmosphere $\left.\operatorname{Ar}(a), \operatorname{Ar}(80 \%)+\mathrm{O}_{2}(20 \%)(b), \operatorname{Ar}(70 \%)+\mathrm{O}_{2}(30 \%)(c)\right]$

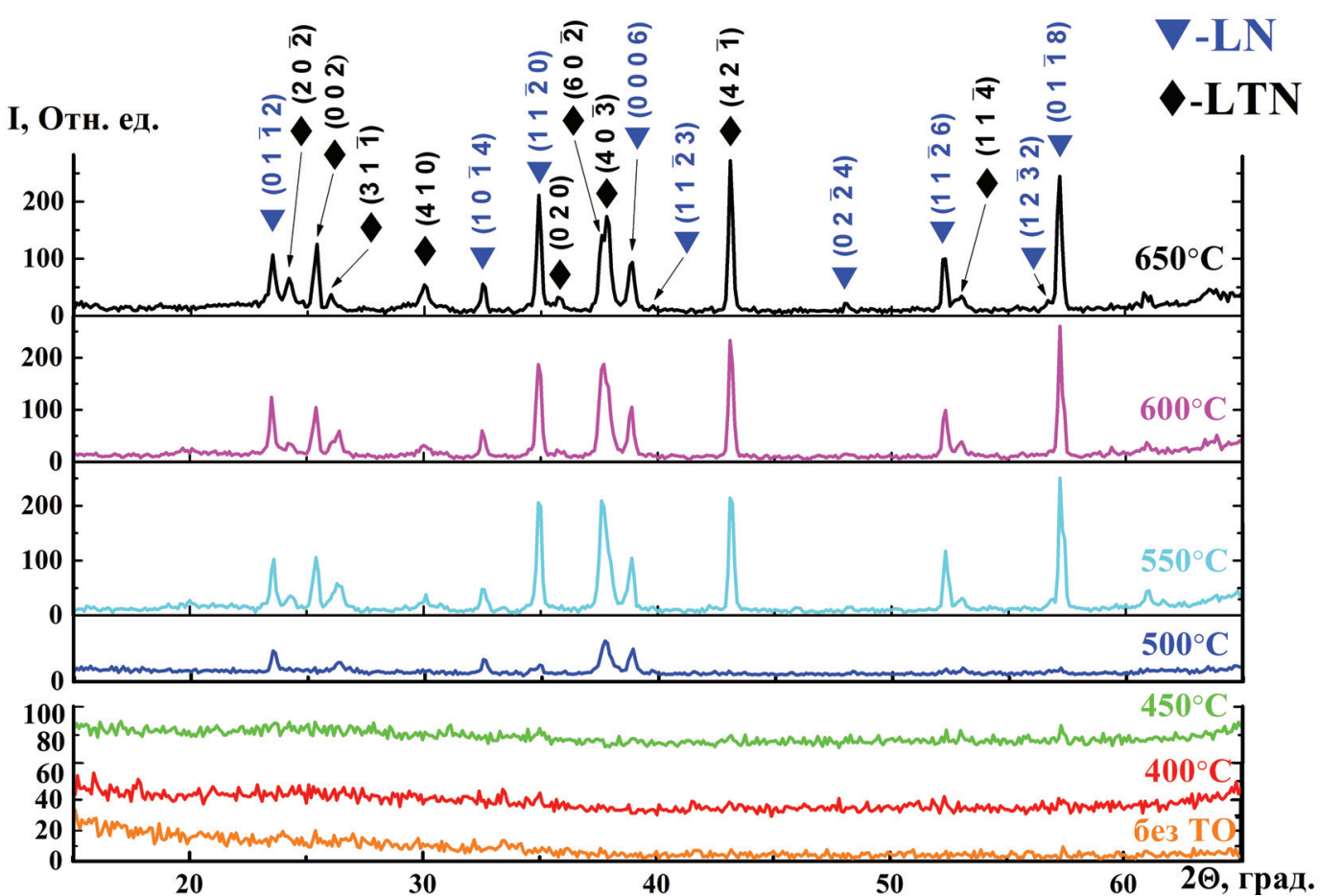

Рис. 5. Рентгеновские дифрактограммы пленки на основе LN, в процессе термической обработки in situ в рентгеновском дифрактометре

[Fig. 5. X-ray patterns of the film based on LN during in situ heat treatment in an X-ray diffractometer] 
чем свидетельствует уменьшение пиков LTN (31 $\overline{1})$ и $(60 \overline{2})$ и увеличение пика $(40 \overline{3})$.

На рис. 6 представлены ПЭМ-изображения и электронограммы аморфных пленок, полученных в процессе ВЧМР на неподогреваемых подложках, после ИФО (с дозой облучения 80 и $130 \mathrm{~J} / \mathrm{cm}^{2}$ ) и БТО. Установлено, что ИФО и БТО приводят к кристаллизации аморфной пленки с образованием однофазного нанокристаллического ниобата лития с произвольной ориентацией зерен. Размер зерен ниобата лития после однократной обработки одинаков для пленок, расположенных с облучаемой и необлучаемой сторон. Максимальный размер зерен после шестикратной ИФО для пленки, расположенной на облучаемой стороне гетероструктуры, значительно превышает максимальный размер зерен пленки, расположенной с обратной стороны: 60 и 40 nm после ИФО и БТО соответственно.

Таким образом, можно сделать вывод, что субструктура пленок с облученной и необлученной стороны зависит от удельной дозы энергии, поступающей на образцы. Предположительно вклад атермической составляющей при высоких значениях дозы облучения $\left(E_{\text {и }}=130 \mathrm{~J} / \mathrm{cm}^{2}\right)$ в процессы кристаллизации и рекристаллизации пленок на облучаемой стороне незначителен. В случае понижения удельной дозы энергии до $E_{\text {и }}=80 \mathrm{~J} / \mathrm{cm}^{2}$ вклад атермической составляющей предположительно возрастает, что приводит к более интенсивной рекристаллизации пленок с облучаемой стороны.

\section{ВЫВОДЫ}

Установлено, что начальные стадии роста пленок ниобата лития в процессе ВЧМР на подогретой до $550{ }^{\circ} \mathrm{C}(001) \mathrm{Si}$ подложке характеризуются островковым зарождением кристаллитов и последующей их коалесценцией.

Показана возможность управления текстурой пленок ниобата лития в процессе ВЧМР в условиях воздействия плазмы ВЧ-разряда, путем изменения состава рабочего газа.

Показан эффект ИФО, в кристаллизации аморфных пленок состава ниобата лития, заключающийся в формировании однофазной нанокристаллической пленки ниобата лития, в процессе обработки на воздухе, в отличие от термической обработки, при которой формируется двухфазная пленка LN + LTN.

\section{ИСТОЧНИК ФИНАНСИРОВАНИЯ}

Исследование выполнено при финансовой поддержке РФФИ, проект № 18-33-00836.

\section{КОНФЛИКТ ИНТЕРЕСОВ}

Авторы декларируют отсутствие явных и потенциальных конфликтов интересов, связанных с публикацией настоящей статьи.
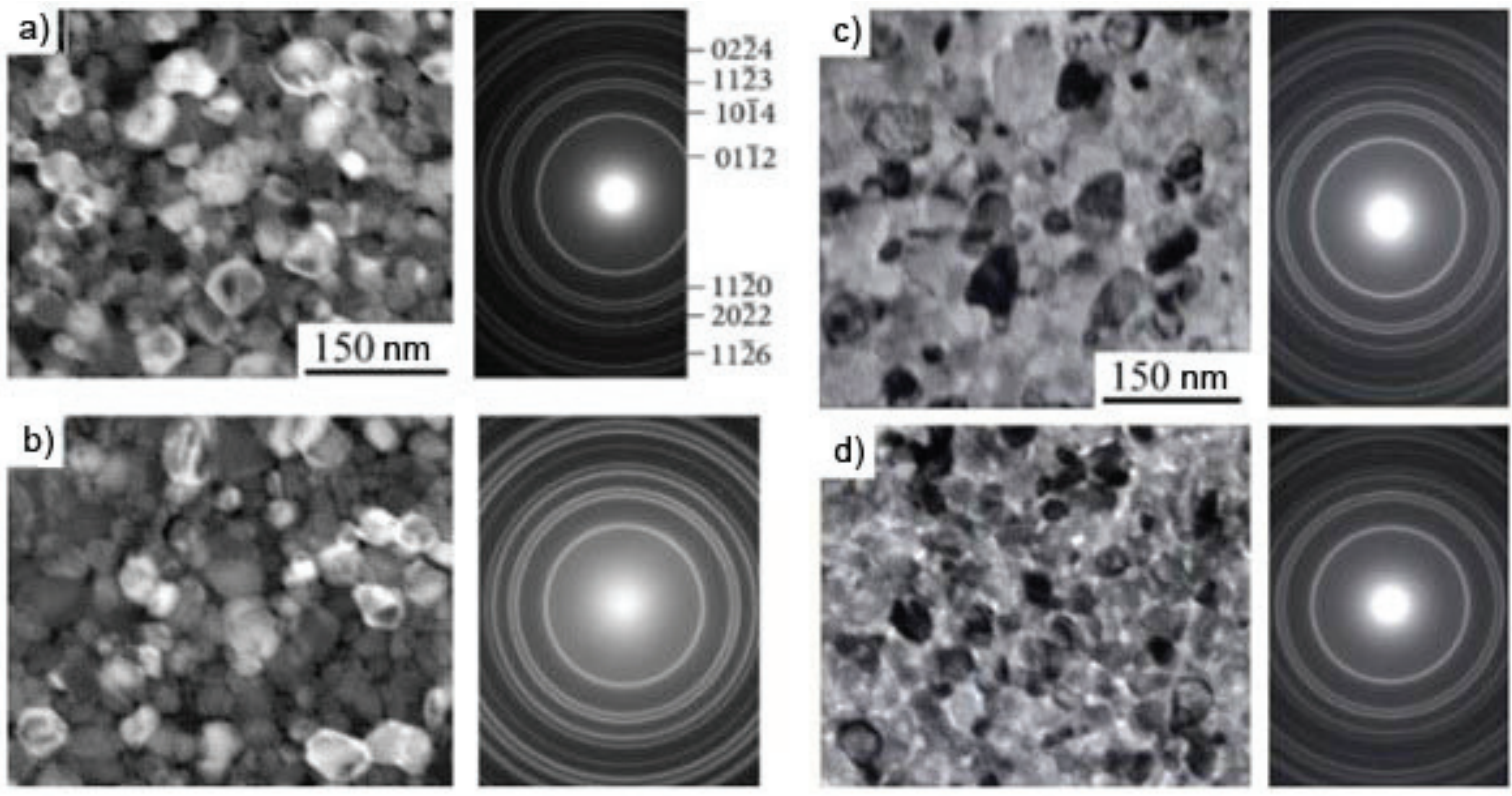

Рис. 6. ПЭМ изображения и электронограммы плёнок ниобата лития после однократных ИФО $(a)$ и БТО $(b)$ а также после шестикратных ИФО $(c)$ и БТО $(d)$

[Fig. 6. TEM images and electron diffraction patterns of lithium niobate films after single PPT $(a)$ and FTA $(b)$ and six fold PPT $(c)$ and FTA $(d)]$ 


\section{СПИСОК ЛИТЕРАТУРЫ}

1. Lu Y, Dekker P., Dawes J. M. // Journal of Crystal Growth, 2009, vol. 311, pp. 1441-1445. DOI: 10.1016/ j.jcrysgro.2008.12.035

2. Poghosyan A. R., Guo R., Manukyan A. L., Grigoryana S. G. // SPIE, 2007, vol. 6698, pp. 1-5. DOI: $10.1117 / 12.734353$

3. Kadota M., Suzuki Y., Ito Y. // Japanese Journal of Applied Physics, 2011, vol. 50, pp. 1-5. DOI: 10.1143/ JJAP.50.07HD10

4. Hao L., Li Y., Zhu J., Wu Z., Wang J., Liu X., Zhang W. // Journal of Alloys and Compounds, 2014, vol. 599, pp. 108-113. DOI: 10.1016/j.jallcom.2014.02.078

5. Gupta V., Bhattacharya P., Yuzyuk Yu. I., Katiyar R. S. // J. Mater. Res., 2004, vol. 19, № 8, pp. 2235-2239. DOI: 10.1557/JMR.2004.0322

6. Tan S., Gilbert T., Hung C.-Y., and Schlesinger T. E. // Appl. Phys. Lett, 1996, vol. 68, p. 2651. DOI: $10.1063 / 1.116270$

UDC 538.9

DOI: $10.17308 / \mathrm{kcmf} .2019 .21 / 716$

Received 03.12.2018

Accepted 15.02.2019
7. Shih W.-C., Sun X.-Y. // Physica B: Condensed Matter, 2010, vol. 405, № 6, pp. 1619-623. DOI: 10.1016/j. physb.2009.12.054

8. Баринов С. М., Белоногов Е. К., Иевлев В. М. и др. // ДАН, 2007, т. 412, № 3, с. 347-350.

9. Hansen P. J., Terao Y., Wu Y., York R. A., Mishra U. K., Speck J. S // J. Vac. Sci. Technol., 2005, vol. 23, № 1, pp. 162-167. DOI: 10.1116/1.1850106

10. Sumets M., Ievlev V., Kostyuchenko A., Vakhtel V., Kannykin S., Kobzev A. // Thin Solid Films, 2014, vol. 552, pp. 32-38. DOI: 10.1016/j.tsf.2013.12.005

11. Seok-Won Choi, et al. // The Korean Journal of Ceramics, 2000, vol. 6, № 2, pp. 138-142.

12. Иевлев В. М., Солдатенко С. А., Кущев С. Б., Горожанкин Ю. В. // Неорганические материаль, 2008, т. 44, № 7, c. 808-815. DOI: 10.1134/S0020168508070066

13. Иевлев В. М., Тураева Т. Л., Латышев А. Н. и др. // Физика металлов и металловедение, 2007, т. 103, № 1, с. 6166 .

\title{
GROWN AND SUBSTRUCTURE OF LITHIUM NIOBATE FILMS
}

\author{
(C) 2019 V. A. Dybov ${ }^{* 1}$, D. V. Serikov ${ }^{1}$, G. S. Ryzhkova ${ }^{1}$, A. I. Dontsov ${ }^{1}$ \\ ${ }^{1}$ Voronezh State Technical University \\ 14, Moscow ave., 394026 Voronezh, Russian Federation \\ ${ }^{2}$ Voronezh State University \\ 1, Universitetskaya pl., 394018 Voronezh, Russian Federation
}

\begin{abstract}
Objective. Radio frequency magnetron sputtering (RFMS) is one of the most promising methods of synthesis of lithium niobate films. It is known that RFMS conditions (the composition and the pressure of the working gas and the power and the spatial inhomogeneity of plasma discharge) offer great opportunities for controlling the structure of complex composition films and their texture in particular. Currently, no publications have described research dedicated to the earliest stages of the growth of lithium niobate films during RFMS or on any substrates.

The aim of the work is to study the initial stages of the growth and the oriented crystallization of lithium niobate films in the process of RFMS and TA, PPT, and FTA on a Si substrate.

Methods and methodology. Lithium niobate films with a thickness of up to $1 \mu \mathrm{m}$ were obtained by the method of radio frequency magnetron sputtering (RFMS) on non-heated and heated (up to $550{ }^{\circ} \mathrm{C}$ ) substrates. The single-crystal $\mathrm{LiNbO}_{3}$ plates of the (0001) orientation obtained by the Czochralski method were used as the target. RFMS was performed in Ar medium and $\mathrm{Ar}+\mathrm{O}_{2}$ mixtures (the fraction of $\mathrm{O}_{2}$ content in the mixture ranged from 20 to $30 \%$ ) with a specific power of the highfrequency discharge of $15-30 \mathrm{~W} / \mathrm{cm}^{2}$. Plates of single-crystal $\mathrm{Si}(001)$ orientation and heterostructures of an amorphous $\mathrm{SiO}_{2}-\mathrm{Si}$ - amorphous $\mathrm{SiO}_{2}$ film were used as substrates. To study the initial growth stages of coatings using the TEM method, a carbon replica was deposited on the resulting films with a thickness of up to $100 \mathrm{~nm}$ (the duration of the RFMS process $-0.5-7 \mathrm{~min}$ ) and then separated from the substrate $(\mathrm{Si})$ together with the test coating in a mixture of $\mathrm{H}_{2} \mathrm{O}+\mathrm{HNO}_{3}+\mathrm{HF}$. Thermal annealing (TA) of samples in air was performed in situ in an ARL X'TRA Thermo Techno X-ray diffractometer chamber, an Anton Paar 1200N furnace. Pulsed photon treatment (PPT) was carried out on the
\end{abstract}

$\triangle$ Dybov Vladislav A., e-mail: dybovvlad@gmail.com 
upgraded installation UOLP-1M in air: at an energy density of $E_{i}=130 \mathrm{~J} / \mathrm{cm}^{2}$ and with $E_{i}=80 \mathrm{~J} / \mathrm{cm}^{2}$. The phase composition, substructure, and morphological features of the films were investigated by X-ray diffractometry (Bruker D2 Phaser, ARL X'TRA Thermo Techno), electron diffraction (EG$100 \mathrm{M}$ ), and electron microscopy (ZEISS Libra 120, EMV-100BR); the analysis of the elemental composition was performed by electron Auger spectroscopy on an ESO-3 instrument with a DESA-100 analyzer.

Results. It is established that the initial stages of the growth of lithium niobate films during the HFMR process on a substrate Si heated to $550{ }^{\circ} \mathrm{C}(001)$ are characterized by island nucleation of crystallites and their subsequent coalescence. The research shows the possibility of controlling the texture of lithium niobate films in the process of RFMS under the conditions of exposure to plasma of an RF discharge by changing the composition of the working gas. The PPT effect is manifested in the crystallization of amorphous lithium niobate films that involves the formation of a single-phase nanocrystalline film of lithium niobate when treated in air in contrast to thermal treatment which results in the formation of a two-phase LN + LTN film.

Conclusion. The obtained results favour the use of lithium niobate films as a material for functional ferroelectric elements, for optoelectronics (optical waveguides, ring microresonators), acoustoelectronics (piezoelectric transducers in delay lines, filters), and semiconductor electronics (nonvolatile FRAM cell). This can significantly simplify the manufacturing technology of such elements and allow them to be introduced into the production of conventional CMOS structures while at the same time making some additions to the existing technology.

Keywords: lithium niobate, thin films, radiofrequency magnetron sputtering, grown, structure, thermal treatment, pulsed photon treatment.

\section{SOURCE OF FINANCING}

The reported study was supported by the Russian Foundation for Basic Research (grant No. 1833-00836).

\section{CONFLICT OF INTEREST}

The authors declare the absence of obvious and potential conflicts of interest related to the publication of this article.

\section{REFERENCES}

1. Lu Y, Dekker P., Dawes J.M. Journal of Crystal Growth, 2009, vol. 311, pp. 1441-1445. DOI: 10.1016/ j.jcrysgro.2008.12.035

2. Poghosyan A. R., Guo R., Manukyan A. L., Grigoryana S. G. SPIE, 2007, vol. 6698, pp. 1-5. DOI: $10.1117 / 12.734353$

3. Kadota M., Suzuki Y., Ito Y. Japanese Journal of Applied Physics, 2011, vol. 50, pp. 1-5. DOI: 10.1143/ JJAP.50.07HD10

4. Hao L., Li Y., Zhu J., Wu Z., Wang J., Liu X., Zhang W. Journal of Alloys and Compounds, 2014, vol. 599, pp. 108-113. DOI: 10.1016/j.jallcom.2014.02.078
5. Gupta V., Bhattacharya P., Yuzyuk Yu. I., Katiyar R. S. J. Mater. Res., 2004, vol. 19, N 8, pp. 2235-2239. DOI: 10.1557/JMR.2004.0322

6. Tan S., Gilbert T., Hung C.-Y., and Schlesinger T. E. Appl. Phys. Lett., 1996, vol. 68, p. 2651. DOI: 10.1063/1.116270

7. Shih W.-C., Sun X.-Y. Physica B: Condensed Matter, 2010, vol. 405, no. 6, pp. 1619-623. DOI: 10.1016/j. physb.2009.12.054

8. Barinov S. M., Belonogov E. K., Ievlev V. M., et al. Doklady Physical Chemistry, 2007, vol. 412, no. 1, pp. 1518. DOI: 10.1134/s0012501607010058

9. Hansen P. J., Terao Y., Wu Y., York R. A., Mishra U. K., Speck J. S. J. Vac. Sci. Technol., 2005, vol. 23, № 1, pp. 162-167. DOI: 10.1116/1.1850106

10. Sumets M., Ievlev V., Kostyuchenko A., Vakhtel V., Kannykin S., Kobzev A. Thin Solid Films, 2014, vol. 552, pp. 32-38. DOI: 10.1016/j.tsf.2013.12.005

11. Seok-Won Choi, et al. The Korean Journal of Ceramics, 2000, vol. 6, no. 20, pp. 138-142.

12. Ievlev V. M., Soldatenko S. A., Kushhev S. B., Gorozhankin Ju. V. Inorganic Materials, 2008, vol. 44, no. 7, pp. 705-712. DOI: 10.1134/s0020168508070066

13. Ievlev V. M., Turaeva T. L., Latyshev A. N., et al. The Physics of Metals and Metallography, 2007, vol. 103, no. 1, pp. 58-63. DOI: 10.1134/s0031918x07010073 
Дьбов Владислав Анатольевич - м. н. с., Воронежский государственный технический университет, Воронеж, Российская Федерация; e-mail: dybovvlad@gmail.com. ORCID iD 0000-0003-2940-0473.

Сериков Дмитрий Владимирович - м. н. с., Воронежский государственный технический университет, Воронеж, Российская Федерация; e-mail: dmitriy.tut@mail.ru. ORCID iD 0000-0002-0464-3500.

Рыжкова Галина Сергеевна - магистр, Воронежский государственный технический университет, Воронеж, Российская Федерация; e-mail: g.rizhkova33@yandex.ru. ORCID iD 0000-00033494-3579.

Дониов Алексей Игоревич - к. ф-м. н., преподаватель кафедры материаловедения и индустрии наносистем, Воронежский государственный университет, Воронеж, Российская Федерация; e-mail: dontalex@mail.ru. ORCID iD 0000-00023645-1626.
Dybov Vladislav A. - Junior Researcher, Voronezh State Technical University, Voronezh, Russian Federation; e-mail: dybovvlad@gmail.com. ORCID iD 00000003-2940-0473.

Serikov Dmitrii V. - Junior Researcher, Voronezh State Technical University, Voronezh, Russian Federation; e-mail: dmitriy.tut@mail.ru. ORCID iD 00000002-0464-3500.

Ryzhkova Galina S. - Master's degree, Voronezh State Technical University, Voronezh, Russian Federation; e-mail: g.rizhkova33@yandex.ru. ORCID iD 0000-0003-3494-3579.

Dontsov Aleksey I. - Cand. Sci. (Phys.-Math.), Scientific Researcher of Materials Science and Industry of Nanosystems Department, Voronezh State University, Voronezh, Russian Federation; e-mail: dontalex@mail. ru. ORCID iD 0000-0002-3645-1626. 